\title{
RADIOCARBON DATING OF BURIED HOLOCENE SOILS IN SIBERIA
}

\author{
Lyubov A Orlova ${ }^{1}$ Valentina S Zykina \\ Institute of Geology, Siberian Branch of the Russian Academy of Sciences, Koptuyg Ave. 3, Novosibirsk 630090, Russia
}

\begin{abstract}
We have constructed a detailed chronological description of soil formation and its environments with data obtained on radiocarbon ages, palynology, and pedology of the Holocene buried soils in the forest steppe of western and central Siberia. We studied a number of Holocene sections, which were located in different geomorphic situations. Radiocarbon dating of materials from several soil horizons, including soil organic matter (SOM), wood, peat, charcoal, and carbonates, revealed three climatic periods and five stages of soil formation in the second part of the Holocene. ${ }^{14} \mathrm{C}$ ages of approximately $6355 \mathrm{BP}, 6020 \mathrm{BP}$, and $5930 \mathrm{BP}$ showed that the longest and most active stage is associated with the Holocene Climatic Optimum, when dark-grey soils were formed in the forest environment. The conditions of birch forest steppe favored formation of chernozem and associated meadow-chernozem and meadow soils. Subboreal time includes two stages of soil formation corresponding to lake regressions, which were less intense than those of the Holocene Optimum. The soils of that time are chernozem, grassland-chernozem, and saline types, interbedded with thin peat layers ${ }^{14} \mathrm{C}$ dated to around $4555 \mathrm{BP}, 4240 \mathrm{BP}$ and $3480 \mathrm{BP}$, and $3170 \mathrm{BP}$. Subatlantic time includes two poorly developed hydromorphic paleosols formed within inshore parts of lakes and chernozem-type automorphic paleosol. The older horizon was formed during approximately 2500 $1770 \mathrm{BP}$, and the younger one during approximately 1640-400 BP. The buried soils of the Subatlantic time period also attest to short episodes of lake regression. The climate changes show an evident trend: in the second part of the Atlantic time period it was warmer and drier than at present, and in the Subboreal and Subatlantic time periods the climate was cool and humid.
\end{abstract}

\section{INTRODUCTION}

Soil evolution provides clues for the reconstruction of Holocene environments and prediction of future climate changes. Radiocarbon $\left({ }^{14} \mathrm{C}\right)$ dating is a powerful tool for the investigation of genesis, geography, and evolution of soils. We studied several sections of Holocene deposits in forest steppe zones of western and central Siberia, and dated paleosols by the ${ }^{14} \mathrm{C}$ method (Figure 1). This allows us a deeper insight in the history of the Holocene climates and soil dynamics.

\section{METHODS}

Recently, there has been a broad discussion of the methods of sample pretreatment and the interpretation of ${ }^{14} \mathrm{C}$ soil dating results (e.g., Chichagova 1985; Chichagova and Cherkinsky 1987; Scharpenseel 1971; Polach and Kostin 1971; Orlova and Panychev 1993; etc.).

To separate soil organics for dating, we use Turin's method (see Arslanov and Kozyreva 1976). Soil organic matter (SOM) is divided into the following fractions: 1) free humic acids-fulvic acids, 2) humic acids bound with $\mathrm{Ca}$ and $\mathrm{R}_{2} \mathrm{O}_{3}$ mobile species-fraction I, 3) humic acids bound with $\mathrm{R}_{2} \mathrm{O}_{3}$ stable forms (more firmly attached to the mineral fraction) - fraction II, 4) humin; and 5) soil remnant.

We sift a dry soil sample, ranging from 3 to $20 \mathrm{~kg}$, through a sieve (minimal cell size $=0.25 \mathrm{~mm}$ ) without grinding so as not to contaminate the sample with plant or animal organic remnants. Then we mechanically remove foreign material (e.g., seeds, grass roots, insect remains). The sample is inspected further under a binocular microscope, and placed into 20 - $\mathrm{L}$ glass vessels; we then add $0.1 \mathrm{~N} \mathrm{NaOH}$ solution at room temperature. To precipitate clay particles, we add $40 \mathrm{~g}$ of $\mathrm{Na}_{2} \mathrm{SO}_{4}$. Distilled water is added to each container to bring the volume up to $10 \mathrm{~L}$. The mixture is stirred several times during the day, and left overnight. The next day, the solution is siphoned and precipitated by adding concentrated $\mathrm{H}_{2} \mathrm{SO}_{4}$ and heated to $80{ }^{\circ} \mathrm{C}$. The precipitate is collected, filtered with a Bûchner funnel containing a double glass-fiber filter, washed in distilled water, and dried at $105^{\circ} \mathrm{C}$. The remaining soil is decalcified with $0.1 \mathrm{~N} \mathrm{H}_{2} \mathrm{SO}_{4}$, or with $0.1 \mathrm{~N} \mathrm{HCl}$ solution in the case of car-

${ }^{1}$ Corresponding author. Email: orlova@uiggm.nsc.ru. 
bonate soils. Then it is washed with distilled water until no $\mathrm{Ca}^{2+}$ appears in the filtrate. The decalcified soil is treated $2-3$ times with $0.1 \mathrm{~N} \mathrm{NaOH}$ at room temperature. The alkaline solution is siphoned, and humic acids are precipitated by adding $0.1 \mathrm{~N} \mathrm{H}_{2} \mathrm{SO}_{4}$. Humic acids are then dried for production of benzene. This fraction I of humic acids is bound with $\mathrm{Ca}$ and mobile $\mathrm{R}_{2} \mathrm{O}_{3}$ forms. The remaining soil is treated alternately with $0.1 \mathrm{~N} \mathrm{H}_{2} \mathrm{SO}_{4}$ and $\mathrm{NaOH}$ solutions 2-3 times. The alkaline filtrate is collected and the fraction II of humic acids is separated, more firmly bound to mineral phases. Then the soil is placed into a stainless steel water bath, mixed with $0.1 \mathrm{~N} \mathrm{NaOH}$ solution, and heated to $80-90^{\circ} \mathrm{C}$ for $2-3 \mathrm{hr}$. This hot treatment is repeated $2-3$ times. The alkaline filtrate is siphoned, and the humin fraction is prepared by the same separation methods. Finally, the soil remnant is washed with acidified water, dried at $105^{\circ} \mathrm{C}$, and dated by ${ }^{14} \mathrm{C}$.

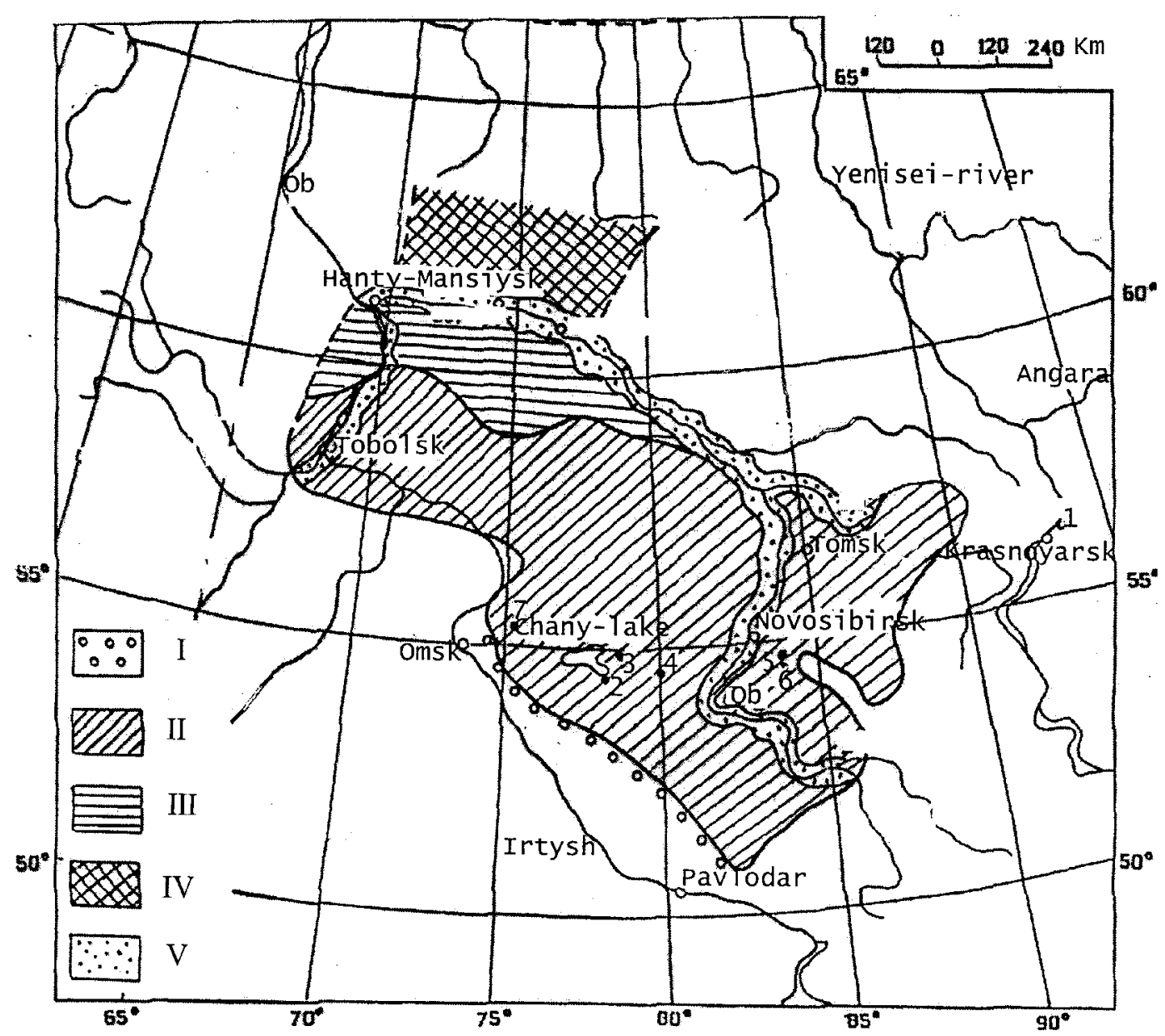

Figure 1 Holocene soils in western Siberia (Atlantic period): steppe (I), forested steppe (II), southern taiga subzone (III), middle-taiga subzone (IV), alluvial soils (V). Sections: 1 = Nyasha, Yenisei River, 2 = Shirokaya Kurya, Chany Lake, $3=$ Zdvinsk, Chany Lake, 4 = Suma floodplain, Suma River, 5 = Mamonovo, Berd' River, $6=$ Maslyanino, Berd' River, $7=$ Malinino, Om' River. 


\section{RESULTS AND DISCUSSION}

The dated material (Table 1) was sampled from buried peatbogs and paleosols in Holocene sections, located on the first and second lake and river terraces, on elevated floodplains, within lake basins, and in depressions between dunes.

A 5.8-m-thick Holocene section is exposed in a limnic broadening within the Om' River valley near the village of Malinino. The section contains two paleosols. Fraction I of humic acids, taken at the base of the upper 0.8-m-thick paleosol with well-developed genetic horizons, was dated to $1170 \pm$ $85 \mathrm{BP}$ (SOAN-1968A), and fraction II gave a ${ }^{14} \mathrm{C}$ value of $2240 \pm 50 \mathrm{BP}$ (SOAN-1968B). The upper $5 \mathrm{~cm}$ of the humus horizon revealed three ${ }^{14} \mathrm{C}$ ages: $570 \pm 100 \mathrm{BP}$ (SOAN-1969A) for fraction I; 790 $\pm 60 \mathrm{BP}$ (SOAN-1969B) for fraction II, and $680 \pm 85 \mathrm{BP}$ (SOAN-1969C) for the humin fraction. The age of total I + II fraction from the 0.10-m-thick humus horizon of the lower paleosol, composed of black loamy sand, is $4240 \pm 160 \mathrm{BP}(\mathrm{SOAN}-1967)$.

Subaerial deposits, widely distributed in the Om' River valley, are overlain with fluvial and lacustrine facies. The presence of humus horizons in the section is evidence of repeated regressions. One occurred at around $4240 \mathrm{BP}$, corresponding to the Subboreal period. The age of another regression coincides with the beginning of the Subatlantic, spanning from around 2240 to 570 BP. The soil formed during that time is of chernozem type, and is overlain by lacustrine deposits formed under the wetter climate, which may correspond to the cooling of the Little Ice Age, as evidenced by ${ }^{14} \mathrm{C}$ data (Orlova 1990).

Table $1{ }^{14} \mathrm{C}$ ages of Holocene buried soil horizons of Siberia

\begin{tabular}{|c|c|c|c|c|c|c|c|}
\hline \multirow[b]{2}{*}{ Location } & \multirow{2}{*}{$\begin{array}{l}\text { Depth } \\
\text { (m) }\end{array}$} & \multicolumn{4}{|c|}{ Soil organic matter fractions } & \multirow[b]{2}{*}{ Charcoal } & \multirow[b]{2}{*}{ Peat } \\
\hline & & I & II & Total I + II & Humin & & \\
\hline \multirow[t]{3}{*}{ Malinino } & $1-1.05$ & $570 \pm 100$ & $790 \pm 60$ & & $680 \pm 85$ & & \\
\hline & $1.3-1.4$ & $1170 \pm 85$ & $2240 \pm 50$ & & & & \\
\hline & $2.8-2.9$ & & & $4240 \pm 160$ & & & \\
\hline \multirow[t]{2}{*}{ Mamonovo } & 2.9 & & & & & & $4400 \pm 340$ \\
\hline & 4.0 & & & & & & $5930 \pm 100$ \\
\hline \multirow[t]{2}{*}{ Maslyanino } & $0.5-0.6$ & & & $4720 \pm 50$ & & & \\
\hline & $1.9-2.0$ & & & $1670 \pm 40$ & & $1640 \pm 40$ & \\
\hline Fy asila & $2.1-2.2$ & & & $1900 \pm 40$ & & $1770 \pm 55$ & \\
\hline & $2.2-2.3$ & & & $2480 \pm 45$ & & $2500 \pm 60$ & \\
\hline & $2.8-2.9$ & & & & & $5445 \pm 75$ & \\
\hline \multirow[t]{2}{*}{ Suma-1 } & $1.2-1.3$ & $6020 \pm 90$ & $6345 \pm 140$ & & & & \\
\hline & $1.2-1.3$ & $6320 \pm 120$ & $6030 \pm 150$ & & & & \\
\hline \multirow[t]{3}{*}{ Suma-2 } & $1.1-1.2$ & & & $3480 \pm 55$ & & & \\
\hline & $2.0-2.1$ & & & $4555 \pm 120$ & & & \\
\hline & $2.9-3.0$ & & & $6355 \pm 240$ & & & \\
\hline Chany & 0.3 & & & $1740 \pm 30$ & $1620 \pm 20$ & & \\
\hline Zdvinsk & $0.4-0.5$ & & & $3170 \pm 30$ & & & \\
\hline Malye & 0.4 & & & & & $820 \pm 120$ & \\
\hline Chany & $1.6-1.7$ & & & & & & \\
\hline Shirokaya & 2.35 & & & & & & \\
\hline \multirow[t]{4}{*}{ Kurya } & $2.8-2.9$ & & & & & & \\
\hline & $1.6-1.7$ & $1070 \pm 50$ & $1180 \pm 50$ & & $1035 \pm 40$ & & \\
\hline & 2.35 & $2385 \pm 35$ & $2410 \pm 50$ & & $2265 \pm 40$ & & \\
\hline & $2.8-2.9$ & & & $5530 \pm 210$ & & & \\
\hline
\end{tabular}


A 1.2-1.9-m-thick buried peatbog, located on the first terrace of the Berd' River, was studied near the village of Mamonovo (Firsov and Panychev 1973). The upper portion of the peat layer contains abundant wood fragments, and was ${ }^{14} \mathrm{C}$ dated to $4400 \pm 340 \mathrm{BP}$ (SOAN-114). The lower part of the layer, composed of dark-brown and more consolidated peat, yielded an age of $5930 \pm 100 \mathrm{BP}$ (SOAN-113). According to the spore and pollen record, the peatbog appeared to be in the second part of humid Preboreal time in a birch forest steppe environment. The younger pollen spectra, corresponding to the second part of Atlantic time period, show the bog evolution in birch-pine forest steppe environment when the landscapes were similar to modern ones (Zykina et al. 1981).

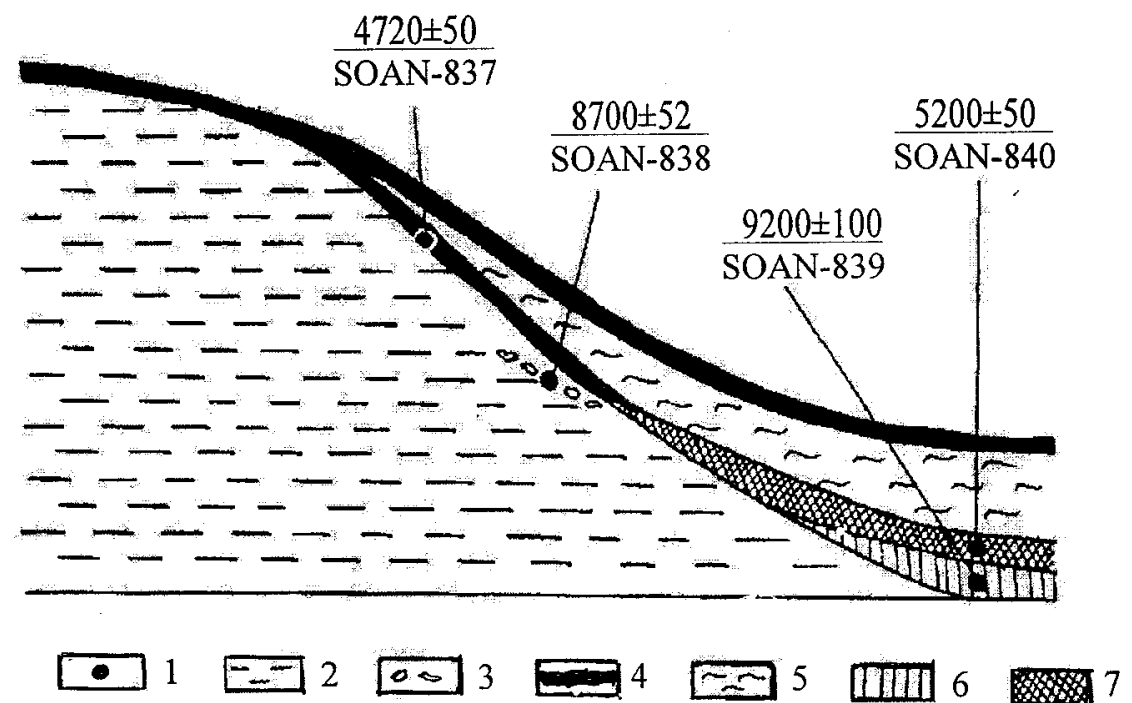

Figure 2 Stratigraphy of Holocene deposits near the village of Maslyanino, Berd' River. $1=$ location of ${ }^{14} \mathrm{C}$ samples, $2=$ silt, $3=$ calcareous concretion, $4=$ soil, $5=$ loam, $6=$ sapropel, $7=$ peat.

We studied another Holocene paleosol in a section of a terrace-like surface, going down to the first Berd' River terrace, in the vicinity of the Maslyanino village (Figure 2). The paleosol consists of a 0.4-m dark-grey humus horizon, and of an illuvial carbonate horizon $0.5 \mathrm{~m}$ below the humus base. Panychev (1979) traced the paleosol for a few hundred meters and noted a transition downslope from chernozem to grassland-chernozem with a well-presented carbonate concretion horizon, and finally to peat-boggy soil in low-lying areas. The total I + II fraction from the humus horizon was dated to $4720 \pm 50 \mathrm{BP}$ (SOAN-837); the humus-bearing layer in the depression was dated to $5200 \pm$ $50 \mathrm{BP}$ (SOAN-840). The age of the carbonate concretions was estimated to be $8700 \pm 50 \mathrm{BP}$ (SOAN-838), and sapropel at the base of the section was dated to $9200 \pm 100$ BP (SOAN-839). Thus, we deal with a catenary succession of soils corresponds to the Atlantic time: chernozemgrassland-chernozem-peat-gleysol. The peat-gleysol soil was formed after the sedimentation interruption, on the surface of the Preboreal time sapropel.

The multilayered archaeological site Nyasha occurs near the edge of the 8-10-m first terrace of the Yenisei River (Drozdov et al. 1998) in a depression between dunes (Figure 3). The section under study contains four paleosols. The uppermost section (paleosol I) consists of dark-grey fine-grained loamy sand. The age of the total I + II fraction from this horizon is $1670 \pm 40 \mathrm{BP}$ (SOAN-3657), and the charcoal sample gave an age of $1640 \pm 40 \mathrm{BP}$ (SOAN-3653). The second paleosol (II) is made up of 25 -cm-thick black fine-grained loamy sand. The age of a charcoal sample from its top is 
A

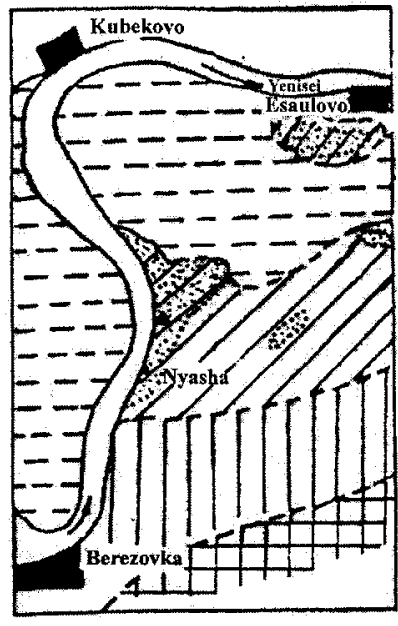

$1 E \exists$

$2 \square$

$3 \square$

4

5

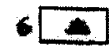

km 0 : 12

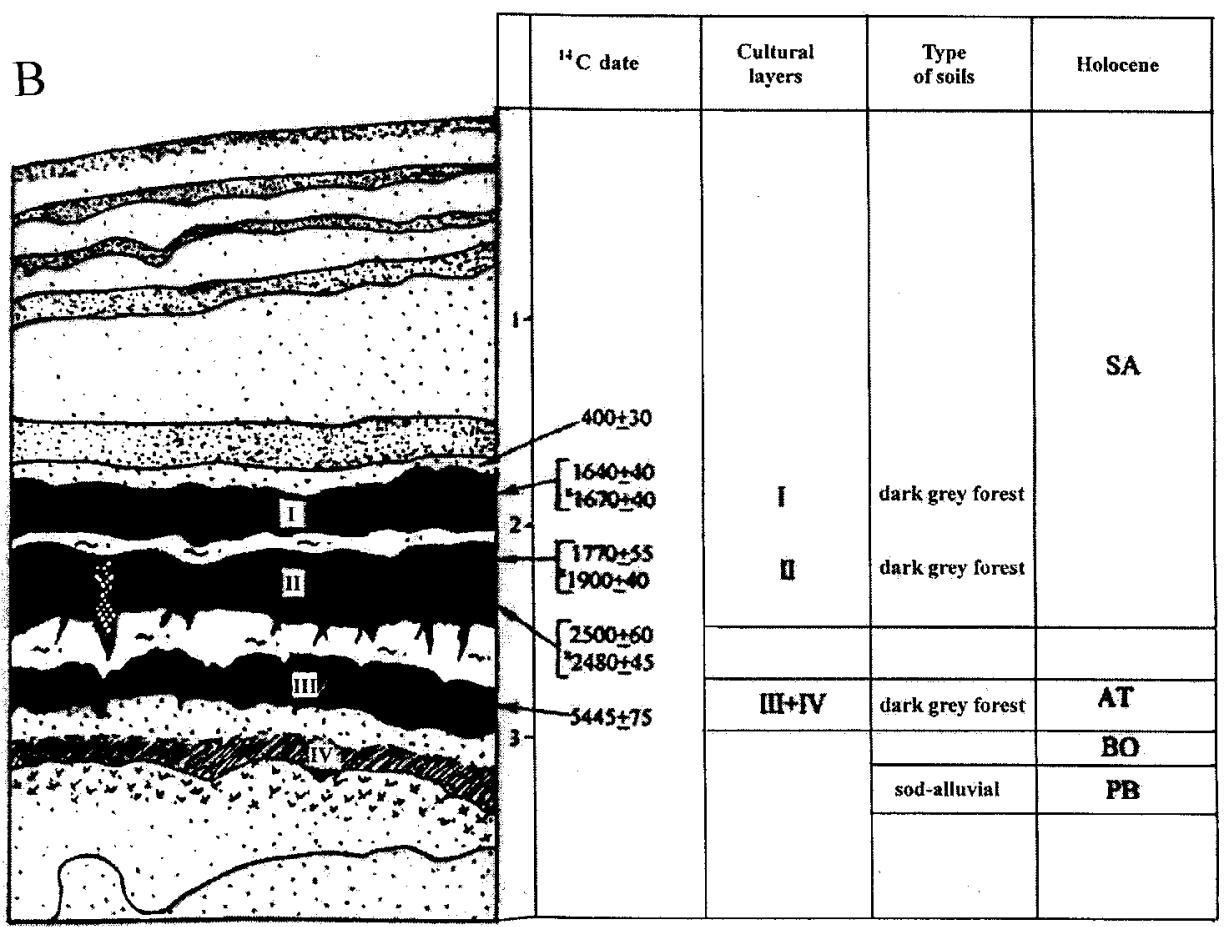

$\cdots$

$\approx 2$

2멸 3

$x \times 4$

5

Figure 3 Geomorphic position and stratigraphy of Holocene deposits exposed in the region of the Neolithic site Nyasha, culture, region of Yenisei River (section 1 in Figure 1). A = Generalized geomorphology. $1=$ floodplain, $2=$ first terrace $(8-12 \mathrm{~m}), 3=$ second terrace $(15-20 \mathrm{~m}), 4=$ third terrace $(30-40 \mathrm{~m}), 5=$ areas of hilly (aeolian) topography, $6=$ location of the Nyasha site. $\mathrm{B}=$ Geological cross-section of the trench (eastern wall). 1 = sand, 2 = loamy sand, 3 = humus content: high (a), medium (b), low (c); $4=$ carbonate concretions, $5=$ burrows of soil-dwelling animals, $6={ }^{14} \mathrm{C}$ ages of total I + II fraction; other ages are on charcoal. 
$1770 \pm 55 \mathrm{BP}$ (SOAN-3654), and a sample from the lower part of the horizon gave a value of 2500 $\pm 60 \mathrm{BP}$ (SOAN-3655). The age of total I + II fraction from the upper $10 \mathrm{~cm}$ of the second paleosol is $1900 \pm 40 \mathrm{BP}$ (SOAN-3658), and that for the lower $10 \mathrm{~cm}$ is $2480 \pm 45 \mathrm{BP}$ (SOAN-3659). The third paleosol (III) is represented by black fine-grained loamy sand, varying in thickness from 10 to $30 \mathrm{~cm}$, and small charcoal fragments were dated to $5454 \pm 75 \mathrm{BP}$ (SOAN-3756). The 20-cm-thick lowermost paleosol (IV) consists of brownish to dark-grey loamy sands, much more consolidated than the overlying paleosols. Thus, three of the four paleosols in the Nyasha section yielded ${ }^{14} \mathrm{C}$ ages from approximately 5445 to 1640 BP. The Holocene Climatic Optimum soil and the two Subatlantic soils are the dark-grey forest type. During the Subboreal time, the intensification of eolian processes is observed, and this caused the activation of denudation.

Palynological evidence from the alluvial floodplain and dune deposits near the Nyasha site (Chekha and Kol'tsova 1990) shows forest-type spectra for the paleosol III. By the time when the Atlantic soil formation was finished, the vegetation was presented by birch forests with admixture of pine, and with poorly developed grass and moss cover. The paleosol II also reveals forest-type pollen spectra. The spectra of the paleosol I are characterized by predominance of forest species pollen (pine, larch, and birch), and the lower part of this horizon contains pollen of larch and fir. At present, the territory is covered by grey forest soils, with absolute dominance of forest-type pollen spectra contain 89-99\% of forest species. The modern pollen spectra reflect the vegetation of pine forests with admixture of birch and larch grow on dunes of the first terrace of Yenisei River, and the vegetation of dark-conifer forests in swampy depressions between dunes. The modern grass and moss cover is poorly developed, but shows a wide diversity of species.

We also studied several sections in the territory of the Suma floodplain, an extended lake-like basin in the Bagan River valley, western Barabinskaya Plain. The eroded layer of the lacustrine sediments is accrued against the deposits of the surrounding ridge-like hills, and thus it is younger than the ridge ones (Orlova 1990). One section was investigated on the periphery of the floodplain where 0.8$\mathrm{m}$-thick steppe-type paleosol is exposed, with a well-differentiated profile and burrows from soildwelling animals. Fraction I from this paleosol was dated to $6020 \pm 90 \mathrm{BP}$ (SOAN-2324A) and 6320 $\pm 120 \mathrm{BP}(\mathrm{SOAN}-2325 \mathrm{~A})$, and fraction II gave ages of $6345 \pm 140 \mathrm{BP}$ (SOAN-2324B) and $6030 \pm$ $150 \mathrm{BP}(\mathrm{SOAN}-2325 \mathrm{~B})$.

Another section of lacustrine deposits of the Suma floodplain was examined in the central part of the basin where their thickness is much greater ( $3.8 \mathrm{~m}$ compared to $1.5 \mathrm{~m}$ in the basin periphery). Here three paleosols were distinguished. The first paleosol (from top to bottom) was dated to $3480 \pm$ 55 BP (SOAN-2132), using total I + II fraction. The 0.96-m-thick second paleosol, which is the saline type, was developed on sands with well-presented genetic horizons. The age of the total I + II fraction is $4555 \pm 120 \mathrm{BP}$ (SOAN-2131). The third paleosol found in the region is 0.35 -m-thick and the age of the total I + II fraction is $6355 \pm 240 \mathrm{BP}$ (SOAN-2130). The ${ }^{14} \mathrm{C}$ data, along with the presence of paleosols among near-shore lacustrine sands, attest that the limnic basin persisted to as late as the Subatlantic time period, and the lake underwent repeated transgressions and regressions.

A section with paleosol containing a well-developed illuvial horizon of the Holocene Climatic Optimum (Figure 4A) was investigated beneath a defense rampart in the vicinity of the Late Bronze Age site on the Chany Lake near the town of Zdvinsk (Zykina et al. 1983). Rampart semi-circles surround the ancient settlement, which consists of three dwellings along the an abrasion-shaped bluff of the Chany Lake young terrace. The total I + II fraction (SOAN-2010A) and humin (SOAN2010B) from the 0.4-m-thick modern soil on the lake terrace surface were dated to $1740 \pm 30 \mathrm{BP}$ and $1620 \pm 20 \mathrm{BP}$, respectively. The age of the 1.1-m-thick paleosol below the rampart is $3170 \pm 30 \mathrm{BP}$ 
(SOAN-2011). Comparison of the soil morphology allows one to assign the paleosols to different sub-types of chernozem series. The soil, which has been forming on the rampart top since the beginning of Subatlantic time, has a morphology proximal to ordinary chernozem species, and the paleosol below the rampart corresponds to leached chernozem.

In the second part of the Holocene, soils of peat-gley and peat-boggy types, varying in age from around 5530 to $820 \mathrm{BP}$, were developed upon lacustrine deposits on the shore of the ChanyLake
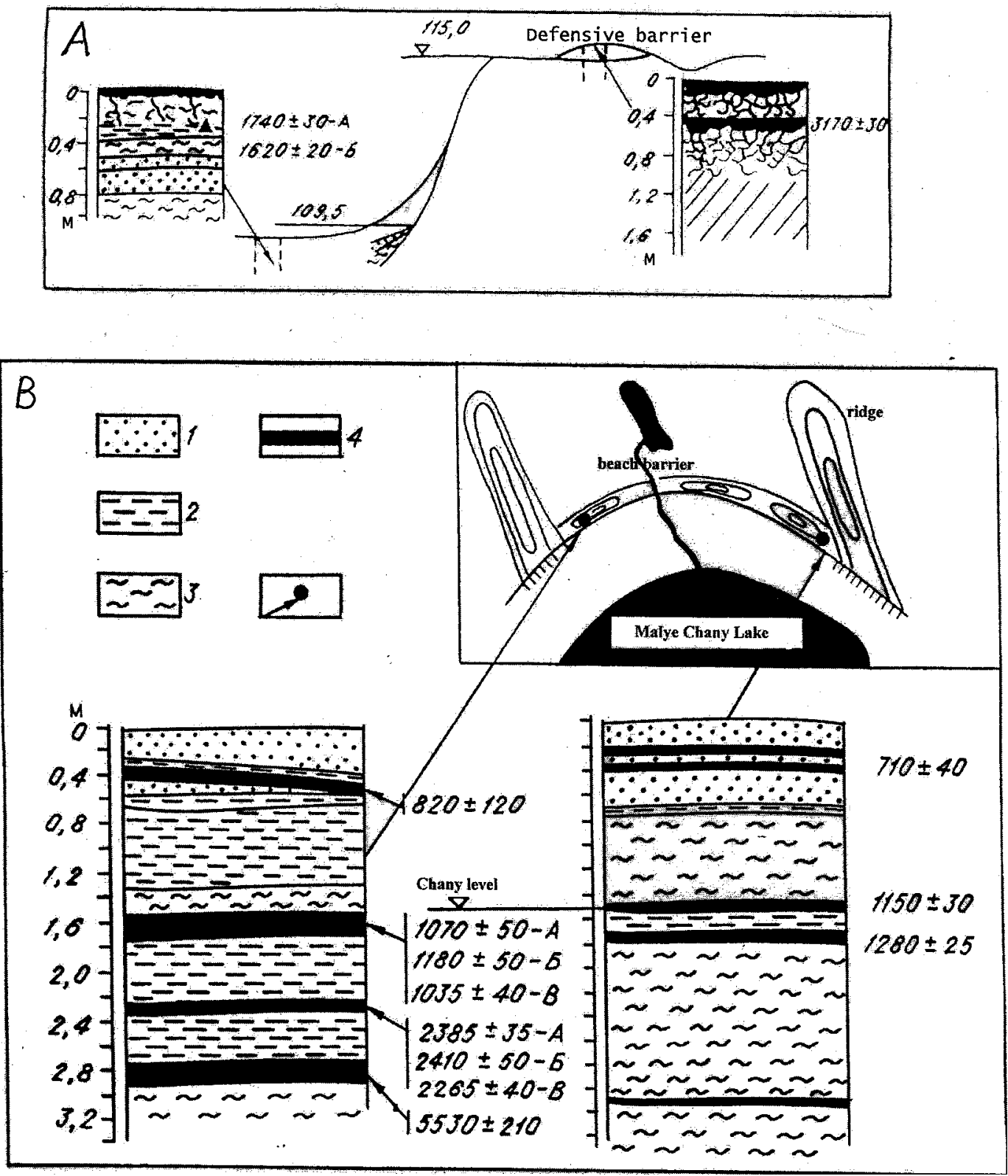

Figure 4 Geomorphic position and stratigraphy of the Holocene deposits of the Chany Lake: $A=$ Zdvinsk, $B=$ Shirokaya Kurya. 1 = sand, 2 = loamy sand, 3 = silts, 4 = peat-gleysol, $5=$ locations of cross-sections. 
(Orlova 1990). The section near the Shirokaya Kurya village on the shore of Malye Chany Lake is of particular interest (Figure 4B). The lake is surrounded from the northeast by an extensive lowland, superposed with a system of elongated hills and valleys between them. There is an ancient coastal ridge 500-800 $\mathrm{m}$ away from the present-day shoreline, its floor $1 \mathrm{~m}$ above the modern lake level, and with a weakly developed soil profile on the top. We studied a section of valley fill that contains four paleosols. The uppermost paleosol is immature and consists of loamy sand, with a thin humus horizon. At the base of the paleosol profile, large Anodonta sp. shells were found, and they yielded an age of $820 \pm 120 \mathrm{BP}$ (SOAN-2099). Below there is a peat-boggy paleosol with two genetic horizons. The ages of its three fractions are: $1070 \pm 50 \mathrm{BP}$ (SOAN-2092A) for fraction I; $1180 \pm 50 \mathrm{BP}$ (SOAN2092B) for fraction II; and $1035 \pm 40 \mathrm{BP}$ (SOAN-2092C) for the humin fraction. The third paleosol consists of humus-bearing loamy sand, and humic acid fractions gave ${ }^{14} \mathrm{C}$ values of $2385 \pm 35 \mathrm{BP}$ (SOAN-2091A, fraction I), $2410 \pm 50 \mathrm{BP}$ (SOAN-2091B, fraction II), and $2265 \pm 40 \mathrm{BP}$ (humin). The fourth paleosol of peat-gleysol type is $0.15 \mathrm{~m}$ thick, and was dated to $5530 \pm 210 \mathrm{BP}$. The lacustrine deposits alternate with the remains of mollusk shells and organic soil layers, which indicates repeated fluctuations of the lake level. The deposition during the highest stand of the lake level involved outwashed sands, loamy sands, and silts. When the lake was dried out, peat-gleysol formed.

In general, the lake underwent four regressions in the second part of the Holocene. As evidenced by ${ }^{14} \mathrm{C}$ ages, the first regression corresponds to the Atlantic time, around $5530 \mathrm{BP}$; the second one occurred in the early Subatlantic period, around 2265-2410 BP. The third regression coincided with the so-called "Small Climatic Optimum", around 1035-1180 BP; the fourth one was dated to around 820 BP. Palynological data show that at around 5530 BP the territory was covered by ferny marshes with shrub birch, xerophyte wormwood-cereal assemblages, and scarce pine-birch groves, and the climate was cold and wet. In the early Subatlantic time, during the second regression at around 2410 $\mathrm{BP}$, vegetation was represented by light pine-birch forests with shrub birch, and the climate was also cold and wet. The third regression at around 1730-1950 BP was accompanied by broad development of pine forest steppe with admixture of elm and lime, and the climate was warm and humid. At around $820 \mathrm{BP}$, during the fourth regression, the climate was again cold and wet and vegetation was represented by light birch and pine forest with shrub birch (Levina and Orlova 1993).

Thus, the studies of paleosols and ${ }^{14} \mathrm{C}$ dating allow us to distinguish several stages of soil formation in the second part of the Holocene. The most intensive and the longest stage coincided with the Climatic Optimum, dated from around 6300 to 5200 BP. Soil formation stages in Subboreal (from around 5200 to $2500 \mathrm{BP}$ ) and Subatlantic (from around $2500 \mathrm{BP}$ until the present) times were weaker and shorter.

The climate of Holocene Optimum, characterized by a number of ${ }^{14} \mathrm{C}$ ages (around $5930 \mathrm{BP}$, 6020 BP, 6355 BP, etc.), was warmer and wetter than now. At that time in the Siberian forest steppe zone, dark-grey soils were formed under birch forest environment, with admixture of pine and spruce. The birch forest steppe conditions were favorable for formation of grassland-chernozem and grassland soil types. The landscapes were similar to those of the present day. On the shores of Chany and Malye Chany lakes, peat-gley soils and peatbogs developed upon lacustrine sediments, which is evidence of the beginning of a regression. Large territories were covered by ferny marshes. Soil formation and humification occurred at higher rates, and the podzolization process was weak. According to paleopedologic evidence, the first part of Atlantic period was more humid than the second part. Subboreal time was characterized by a colder climate and more intensive erosion and sedimentation, which facilitated deflation of the Atlantic soils (Zykin et al. 2000). However, the Subboreal period includes two stages of soil formation as shown by SOM ${ }^{14} \mathrm{C}$ ages of around $3170 \mathrm{BP}, 3480 \mathrm{BP}$ and $4240 \mathrm{BP}$, and $4555 \mathrm{BP}$. However, they were less intensive than those of the Holocene Optimum. 
Both Subboreal stages bear signatures of a short water-basin-level fluctuation, which is evident in the interbedding of chernozem-like, meadow-chernozem, and saline paleosols corresponding to regressions, and thin peat layers also corresponding to transgressions. The climate during the Subatlantic period was likewise cooler and wetter than the climate of the Atlantic period. During the time span from around 2500 to $400 \mathrm{BP}$, as recorded in the Nyasha section, two paleosols were formed but they did not reach the mature profile of the Holocene Optimum. The processes of humification and podzolization at that time were weaker and of shorter duration. The earlier paleosol was developed for about 1000 years, and the formation of the later paleosol took about 700 years. The earlier paleosol was formed under birch forest with shrub species and a weakly developed grass and moss cover. The later paleosol was formed under a pine-larch forest with scarce birches, and grass and moss cover that was also poorly developed. The Subatlantic paleosols in the sections of western Siberia correspond to two stages of soil formation that coincided with lake regressions. In the beginning of the Subatlantic period, ${ }^{14} \mathrm{C}$ dated to around $2240 \mathrm{BP}, 2265 \mathrm{BP}, 2385 \mathrm{BP}$, and $2410 \mathrm{BP}$, the hydromorphic soils formed around lakes and rivers in an environment of light pine-birch forest with shrub birch, and the chernozem soils formed in automorphic environments. From around 1950 to $1130 \mathrm{BP}$, the soil formation was of chernozem, dark-grey forest, and peat-gleysol types in the environment of pine forest steppe, with admixture of elm, lime, and xerophyte wormwood associations.

\section{CONCLUSION}

Original data on ${ }^{14} \mathrm{C}$ ages, palynology, and pedology of the Holocene paleosols of the forest steppe of western and central Siberia allow us to distinguish three climatic periods with five stages of soil formation, differing in intensity and duration. The climate changes show a clearly evident trend: the first part of the Atlantic period was warmer and more humid than at present, and the second part was warmer and drier. The climate was cool and humid during the Subboreal and Subatlantic periods.

\section{ACKNOWLEDGMENTS}

We are grateful to Mr L B Khazin and Mrs T I Perepelova for technical assistance during manuscript preparation and translation, to Dr A E Cherkinsky and an anonymous reviewer for helpful comments and suggestions, and to Dr Y V Kuzmin for grammar correction.

\section{REFERENCES}

Arslanov KhA, Kozyreva MG. 1976. Radiocarbon dating of modern soils. In: Zubakov VA, editor. Geochronology of the USSR. Volume 3: The Northwestern European USSR. Leningrad: Nedra. p 99-113 (in Russian).

Drozdov NI, Zykina VS, Orlova LA, Chekha VP. 1998. A multilayered archaeological site Nyasha in Central Siberia: reconstruction of Holocene environments. In: Derevianko AP, editor. Pleistocene ecology and Stone Age cultures of Northern Asia and the surrounding territories. Proceedings of International Symposium. Novosibirsk: Institute of Archaeology and Ethnography Press. p 355-68 (in Russian).

Chekha VP, Kol'tsova VG. 1990. Geology and palaeogeography of the region of the archaeological site Nyasha. In: Quaternary events and stratigraphy of Eurasia and Pacific region. Abstracts of the International Symposium. Yakutsk: Yakutsk Scientific Center, Siberian Branch of the USSR Academy of Sciences. p 99-101 (in Russian).
Chichagova OA. 1985. Radiocarbon dating of the soil humus. Moscow: Nauka. 158 p (in Russian).

Chichagova OA, Cherkinsky AE. 1987. Radiocarbon studies of the open and close systems (on the example of ${ }^{14} \mathrm{C}$ dating of soils). In: Shukolukov YA, editor. Methods of isotope geology. Abstracts of the AllUnion Symposium. Moscow: Vernadsky's Institute of Geochemistry. p 303-5 (in Russian).

Firsov LV, Panychev VA. 1973. Late Pleistocene-Holocene deposits near the village of Mamonovo, Berd' River (Upper Ob' River basin). In: Saks VN, editor. Pleistocene history of Siberia and adjacent regions. Moscow: Nauka. p 46-51 (in Russian).

Levina TP, Orlova LA. 1993. Holocene climatic rhythms of southern West Siberia. Russian Geology and Geophysics 34(3):36-51.

Orlova LA. 1990. The Baraba region in the Holocene: stratigraphy and radiocarbon chronology. Novosibirsk: Nauka. 128 p. (in Russian). 
Orlova LA, Panychev VA. 1982. Buried soils and reliability of their ${ }^{14} \mathrm{C}$ dating. In: Arkhipov SA, editor. Problems of Pleistocene stratigraphy and palaeogeography of Siberia. Novosibirsk: Nauka. p 28-36 (in Russian).

Orlova LA, Panychev VA. 1993. The reliability of radiocarbon dating buried soils. Radiocarbon 35(3):36977.

Panychev VA. 1979. Radiocarbon chronology of alluvial deposits of the Cis-Altai Plain. Novosibirsk: Nauka. $102 \mathrm{p}$ (in Russian).

Polach HA, Costin AB. 1971. Validity of soil organic matter radiocarbon dated buried soils in snowy mountains suothwestern Australia as example. In: Paleopedology: Origin, nature, and dating of paleosols. Tel Aviv: Foreign Translation Publications. p 86-96.

Scharpenseel HW. 1971. Radiocarbon dating of soil problems, troubles, hopes. In: Paleopedology: origin, nature, and dating of paleosols. Tel Aviv: Foreign
Translation Publications. p 77-81.

Zykin VS, Zykina VS, Orlova LA. 2000. Main peculiarities of environmental and climatic changes of Western Siberia in the Pleistocene and Holocene. In: Markin SV, editor. Problems of the reconstruction of climate and environment of the Holocene and Pleistocene of Siberia. Novosibirsk: Institute of Archaeology and Ethnography Press. p 208-28 (in Russian).

Zykina VS, Volkov IA, Dergacheva MI. 1981. Upper Quaternary deposits and buried soils in the course of the Ob' River, the Novosibirsk Region. Moscow: Nauka. 204 p (in Russian).

Zykina VS, Orlova LA, Panychev VA. 1983. Radiocarbon chronology and palaeogeography of the region of Lake Chany in the Late Bronze and Early Iron Ages. In: Kirushin YF, editor. Applications of methods of natural and exact sciences in studies of the ancient history of Western Siberia. Barnaul: Altai State University. p 11-15 (in Russian). 